\title{
PENGEMBANGAN BAHAN AJAR BERBASIS KASUS (CASE BASED) PADA MATA KULIAH ASPEK HUKUM EKONOMI DAN BISNIS
}

\author{
Sriyani Mentari \\ Nujmatul Laily \\ Universitas Negeri Malang \\ um_elly@yahoo.com
}

\begin{abstract}
This research aims to develop case based learning materials for business and economic law course. The development used Borg and Gall (1983) model that is modified into ten procedure. The main activities of this research are designing and developing learning materials, and 2) validating and revising learning materials. Learning materials is designed into 11 chapters which each chapters consists of: cases, aperseption, learning objective, material and exercises. Validation of learning materials is done by two validators that have competencies in the business law. Validation result of learning materials show that cases are relevan and original where it can motivate the student to have critical thinking. Learning material presentation based on the order from easy to difficult and can achieve the learning objective. Validation results conclude that learning materials are proper and valid and it can be tested in a larger stage.
\end{abstract}

Keywords: Learning material, case based

\begin{abstract}
Penelitian ini bertujuan untuk mengembangkan bahan ajar berbasis kasus pada mata kuliah Aspek Hukum Ekonomi dan Bisnis. Pengembangan bahan ajar menggunakan model rancangan Borg\&Gall yang dimodifikasi dalam 10 langkah prosedur pengembangan. Kegiatan utama penelitian ini meliputi (1) merancang dan mengembangkan bahan ajar, dan (2) memvalidasi serta merevisi bahan ajar. Bahan ajar dirancang dalam 11 (sebelas) bab, di mana setiap bab terdiri dari komponen: contoh kasus, apersepsi, tujuan pembelajaran, materi, dan soal latihan. Validasi bahan ajar dilakukan oleh dua orang validator yang memiliki kompetensi di bidang hukum bisnis. Hasil validasi bahan ajar menunjukkan bahwa: contoh kasus yang digunakan sudah relevan dan orisinil serta dapat memotivasi mahasiswa untuk berpikir kritis. Penyajian materi pembelajaran berdasar urutan dari yang mudah sampai sulit dan dapat mencapai tujuan pembelajaran. Secara keseluruhan hasil validasi dapat disimpulkan bahwa bahan ajar layak dan valid serta dapat dilakukan uji coba pada tahap berikutnya.
\end{abstract}

Kata kunci: Bahan ajar, Berbasis kasus 
Penelitian-penelitian terdahulu telah menemukan bahwa pembelajaran berbasis kasus lebih baik dari metode pembelajaran konvensional, di mana case based teaching dapat meningkatkan kemampuan keterampilan berpikir kritis dan interaksi kelas. Pada metode pembelajaran kasus, pebelajar ditantang untuk menganalisis masalah yang dipresentasikan dalam bentuk kasus, membuat kesimpulan berdasar informasi yang terbatas, membuat keputusan pada ketidakpastian, ambigu, dan isu-isu yang bertentangan yang mensimulasikan dunia nyata ( Kim, et al., 2006). Metode pembelajaran berbasis kasus dapat melatih mahasiswa berpikir holistik, mengkaitkan antar konsep bahkan antar disiplin ilmu. Berbagai disiplin ilmu dalam sejarahnya yang panjang telah menggunakan pembelajaran berbasis kasus, diantaranya disiplin ilmu kedokteran, hukum, bisnis, pendidikan, dan enginering. Dari berbagai disiplin ilmu tersebut, bidang pendidikan dan kedokteran dilaporkan menggunakan paling banyak pembelajaran dengan kasus (Kim, et al., 2006).

Namun demikian, kondisi yang berbeda terjadi dalam dunia pendidikan di Indonesia khususnya di jenjang pendidikan tinggi. Pada jenjang pendidikan tinggi, proses pembelajaran diarahkan agar mahasiswa mampu berpikir kritis dan terampil menyelesaikan masalah. Namun kenyataannya justru sebaliknya, proses belajar mengajar masih 'theory oriented' dengan pendekatan dan cara-cara pembelajaran yang konvensional yaitu ceramah, tanya jawab, dan diskusi. Diskusi juga berjalan secara searah yang dicirikan dengan rendahnya partisipasi audience, tingkatan kognitif pertanyaan yang berkisar kognitif 1- kognitif 3 ( C1-C3). Demikian pula penguasaan materi oleh presentator masih sangat terbatas memahami teks (membaca teks/power point) tanpa memahami lebih dalam, mengkaitkan dengan konsep lain ataupun mengkaitkan dengan 'real world'. Jika dikaji secara lebih baik kondisi di atas sebenarnya disebabkan oleh berbagai faktor baik internal maupun eksternal. Faktor internal meliputi: tingkat intelegensi, kurangnya motivasi belajar, terbatasnya jumlah waktu belajar serta kebiasaan belajar yang belum efektif. Adapun faktor eksternal diantaranya mencakup metode pembelajaran, media belajar, ketersediaan dan kualitas bahan ajar yang belum memadai.

Aspek Hukum Ekonomi dan Bisnis merupakan salah satu mata kuliah inti fakultas yang wajib ditempuh oleh mahasiswa program S1 dan D3 pada Fakultas Ekonomi Universitas Negeri Malang. Bobot Satuan Kredit Semester (SKS) mata kuliah 
ini adalah 3 sks. Kompetensi yang diharapkan dalam mata kuliah ini adalah mahasiswa mampu menjelaskan tentang konsep hukum ekonomi bisnis, keterkaitan bisnis dan hukum, serta praktek hukum bisnis dalam dunia nyata.

Masalah yang terjadi dalam proses perkuliahan adalah kurangnya tingkat hasil belajar pada mata kuliah ini. Kurang maksimalnya nilai mata kuliah ini sebenarnya juga sejalan dengan kurangnya kualitas proses pembelajaran selama satu semester. Masalah yang terjadi dalam proses pembelajaran ini yaitu minimnya partisipasi mahasiswa di kelas baik untuk bertanya, berdiskusi maupun menjawab pertanyaan. Rata-rata dalam satu kelas yang berjumlah 40 sampai 45 mahasiswa yang aktif hanya sekitar 4 sampai 5 mahasiswa sedangkan sisanya hanya bersifat pasif yaitu mengumpulkan tugas dan mendengarkan ceramah dosen. Masalah lainnya yaitu rendahnya kualitas proses pembelajaran yang terjadi, hal ini ditandai dengan (1) kurang siapnya mahasiswa ketika dimulai perkuliahan, yaitu dengan indikator mahasiswa seringkali tidak membawa bahan materi yang akan dibahas, membawa bahanpun sering kali belum terbaca, dan ketika diminta untuk mempresentasikan tugas yang dikerjakan di rumah cenderung tidak mau dan tidak bisa mengungkapkan pendapatnya, (2) sikap ketergantungan mahasiswa terhadap ceramah dosen (mahasiswa lebih menyukai jika dosen yang ceramah), rendahnya kuantitas dan kualitas pertanyaan mahasiswa, setiap dosen selesai menjelaskan satu pokok bahasan, maksimal hanya 1-2 mahasiswa yang memberikan feed back bahkan sering terjadi pada kelas-kelas tertentu tidak ada sama sekali yang bertanya, (3) rendahnya kemampuan mahasiswa untuk menjelaskan dan berargumen baik secara lisan maupun tulisan, serta (4) tidak termotivasinya mahasiswa untuk menjawab pertanyaan dosen kecuali ditunjuk .

Masalah tersebut diatas timbul akibat berbagai hal. Berdasar hasil pengamatan penyebabnya diantaranya yaitu 1) kemampuan awal mahasiswa masih kurang, hal ini didukung dengan 2) kurangnya wawasan mahasiswa terhadap masalah hukum ekonomi dan bisnis. Berdasar hasil pengamatan, hal ini terjadi disebabkan oleh sedikitnya informasi yang diperoleh mahasiswa. Informasi yang didapatkan sebagian besar hanya berasal dari kelas (dosen), hal itu pun banyak yang tidak berbekas dalam memori mahasiswa. Mahasiswa kurang termotivasi untuk mengakses informasi dari berbagai media seperti: jurnal, majalah ilmiah, media cetak dan elektronik. Mahasiswa masih menganggap dosen merupakan satu-satunya sumber belajar. Hal ketiga yang menjadi 
penyebab masalah adalah model instruksional yang selama ini berlangsung yaitu metode konvensional: ceramah, merangkum, serta diskusi kelompok. Perkuliahan masih bersifat teacher directed. Adapun faktor penyebab keempat adalah sumber belajar yang tersedia baik berupa buku text, dan bahan ajar sebagian besar atau semua masih cenderung bersifat teoritis. Pada matakuliah Hukum Bisnis, buku-buku yang tersedia hanya menyalin dari Undang-Undang yang berkaitan dengan topik tanpa disertai penjelasan dan contoh baik ilustrasi maupun contoh riil . Berbagai pendekatan pembelajaran di atas telah diterapkan secara variatif, namun hasilnya masih belum efektif serta belum mampu menjadikan mata kuliah Aspek Hukum Bisnis dan Ekonomi menyenangkan dan menarik bagi mahasiswa. Penyebab lainnya budaya belajar mahasiswa yang cenderung hanya menghafal materi tanpa memahami maknanya lebih jauh. Hal ini menyebabkan daya analisis mahasiswa yang rendah dalam memecahkan suatu masalah atau kasus hukum.

Berdasarkan hasil penelitian Anderson (1985) ditemukan bahwa perbedaan kategori-kategori learning outcome disebabkan oleh perbedaan pendekatan instruksional dan proses asesmen yang digunakan. Dengan demikan sebuah pendekatan instruksional dan proses asessmen sangat penting untuk mendapatkan learning outcome yang diharapkan. Masalah yang telah diuraikan sebelumnya kemungkinan juga disebabkan oleh pendekatan instruksional yang tidak mampu menciptakan kompetensi mahasiswa dalam menganalisis dan memecahkan masalah. Metode pengajaran tradisional menekankan pada declarative knowledge berupa fakta, definisi dan kosa kata (Bonner dan Walker, 1994). Adapun metode instruksional yang menekankan pada intellectual skill yakni meliputi konsep, kaidah, dan prosedur untuk memecahkan masalah.

Penilaian kualitas produk pendidikan pertama-tama terlihat pada perkembangan sikap dasar, seperti sikap kritis akademis ilmiah dan kesediaan terus mencari kebenaran (Yumarma, 2006). Oleh karena itu, konsep pendidikan tidak direduksi pada ujian yang hanya mengukur transfer pengetahuan, namun lebih luas, mencakup pembentukan keterampilan (skill) dan sikap dasar (basic attitude), seperti kekritisan, kreativitas dan keterbukaan terhadap inovasi dan aneka penemuan. Semua itu amat diperlukan agar mahasiswa mampu bertahan hidup dan menjawab tantangan yang selalu berkembang. Dalam hal ini, pendidik dituntut tidak sekedar sebagai pentransfer ilmu, namun lebih 
dari itu juga berperan sebagai agen pencerahan. Ditjen Dikti pada bulan April 2003 memberi amanah yang salah satunya adalah penerapan prinsip Student-Centered Learning (SCL) dalam proses pembelajaran (Mutmainah, 2011). SCL dapat diterapkan dengan efektif bilamana dosen mengintegrasikan antara metode pembelajaran dan bahan ajar yang digunakan mengajak mahasiswa untuk berperan aktif belajar menemukan konsep, prinsip, prosedur serta memecahkan masalah/kasus berdasar konsep dan prinsip yang telah dipahami.

Banyaknya bahan ajar yang masih bersifat teoritis secara tidak sadar dan tidak sengaja menyebabkan proses pembelajaran yang banyak dipraktikkan dosen sekarang ini sebagian besar berbentuk ceramah (lecturing). Pada saat mengikuti kuliah atau mendengarkan ceramah, mahasiswa sebatas memahami sambil membuat catatan. Dosen menjadi pusat peran dalam pencapaian hasil pembelajaran dan seakan-akan menjadi satu-satunya sumber ilmu. Pola pembelajaran dosen aktif dengan mahasiswa pasif ini mempunyai efektivitas pembelajaran yang rendah. Efektivitas pembelajaran mahasiswa umumnya terbatas, terjadi pada saat-saat akhir mendekati ujian. Pembelajaran yang diterapkan saat ini berfokus pada pemahaman materi saja. Dari metode yang diterapkan itu, mahasiswa tidak memiliki gambaran penerapan materi pada dunia bisnis. Oleh karena itu bahan ajar yang ada dan metode pembelajaran saat ini belum dapat mengasah kemampuan analisis mahasiswa, kepekaan terhadap permasalahan, melatih pemecahan masalah serta kemampuan mengevaluasi permasalahan secara holistik.

Sehubungan dengan permasalahan seperti yang dijelaskan di atas, bahan ajar yang dikembangkan untuk diterapkan pada matakuliah Aspek Hukum Ekonomi dan Bisnis adalah bahan ajar berbasis kasus. Dengan adanya bahan ajar berbasis kasus ini diharapkan model pembelajaran yang diterapkan juga berbasis kasus (case-based learning). Alasan utama pengembangan bahan ajar berbasis kasus diajukan dalam perkuliahan ini adalah (1) bahwa bahan ajar memerlukan adanya ilustrasi kasus nyata dalam penerapan ilmu; (2) bahan ajar yang tersedia masih berbasis teori, dan (3) membangun alasan kuat pada mahasiswa agar belajar untuk memahami, menyelesaikan masalah, mengaplikasikan materi dalam praktek bisnis. 


\section{METODE}

Penelitian ini merupakan penelitian dan pengembangan (research and development) yaitu penelitian yang bertujuan untuk menghasilkan output dalam bentuk bahan ajar berbasis kasus yang dijabarkan dalam berbagai komponen. Metode yang digunakan dalam penelitian pengembangan ini mengacu kepada metode pengembangan model sebagaimana yang dikemukakan oleh Borg \& Gall (1983) yang mencakup tahapan-tahapan: 1) Penelitian dan pengumpulan data (research and information collecting); 2) Perencanaan (planning); 3) Pengembangan draf produk awal (develop preliminary form of product); 4) Uji coba lapangan awal (preliminary field testing); 5) Merevisi hasil uji coba (main product revision); 6) Uji coba lapangan (main field testing); 7) Penyempurnaan produk hasil uji coba lapangan (operating product revision); 8) Uji pelaksanaan lapangan (operating field testing); 9) Penyempurnaan produk akhir (final product revision); 10) Diseminasi dan implementasi (dissemination and implementation).

Sebagaimana dinyatakan sebelumnya, penelitian pengembangan ini menggunakan model Borg \& Gall (1983), namun untuk kepentingan ini dilakukan modifikasi dengan melakukan 8 langkah. Prosedur pengembangan bahan ajar dirancang dalam bentuk kegiatan sebagai berikut: 1) telaah silabus mata kuliah Aspek Hukum Ekonomi dan Bisnis untuk merumuskan kompetensi-kompetensi khusus yang harus dikuasai mahasiswa; 2) melakukan analisis pembelajaran untuk menentukan struktur kompetensi; 3) menyusun bahan ajar berbasis kasus; 4) evaluasi dan validasi bahan ajar oleh subjec matter expert; 5) revisi I bahan ajar; 6) Uji coba bahan ajar; 7) Revisi II bahan ajar; dan 8) diseminasi dan implementasi. Perbedaannya terletak pada langkah uji coba, di mana pada model Borg \& Gall (1983) menggunakan tiga kali uji coba yaitu uji coba awal, uji coba utama, dan uji coba lapangan. Penelitian ini hanya menggunakan uji coba utama. 
Berikut ini prosedur penelitian tahap I yang disajikan pada gambar 1.

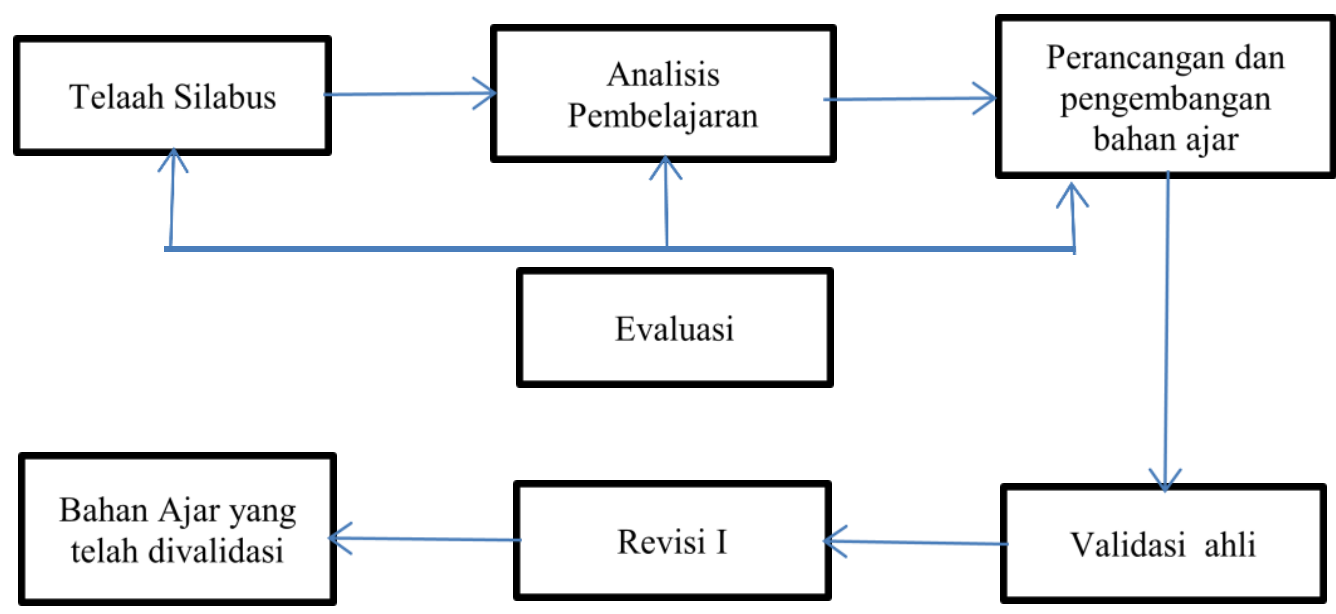

Gambar 1. Prosedur Pengembangan Bahan Ajar Tahap I

Hasil akhir/output penelitian pada tahap I ini adalah bahan ajar berbasis kasus yang telah divalidasi oleh ahli yang selanjutnya akan diuji coba pada tahap II penelitian. Berikut ini prosedur penelitian tahap II dalam bentuk gambar 2.

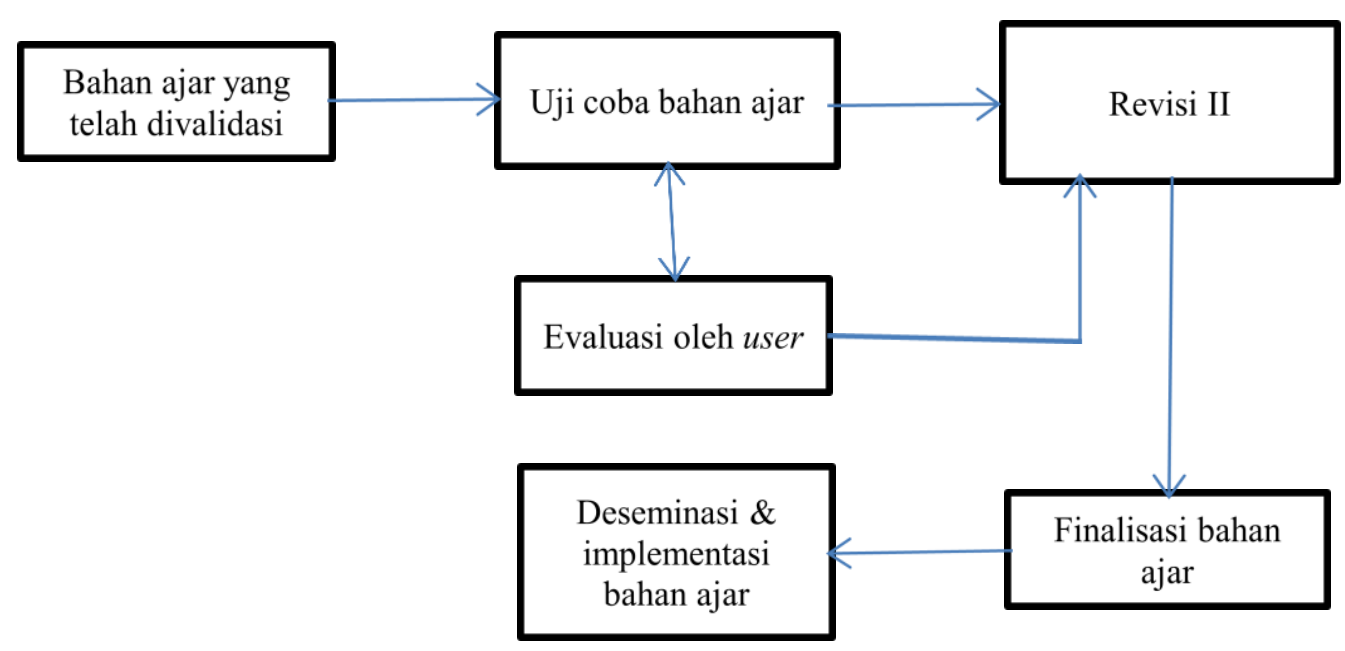

\section{Gambar 2. Prosedur Pengembangan Bahan Ajar Tahap II}

Pada tahun pertama, prosedur pada penelitian ini meliputi telaah silabus, analisis pembelajaran, perancangan dan pengembangan bahan ajar, validasi ahli dan revisi I yang nantinya akan menghasilkan bahan ajar yang telah divalidasi. Sebelum dilakukan telaah silabus, akan dilakukan analisis kebutuhan terlebih dahulu untuk mengetahui 
kesulitan-kesulitan, penyebab, serta ketersediaan bahan ajar yang relevan sehingga dengan informasi ini dapat dijadikan acuan untuk merancang bahan ajar yang sesuai kompetensi dan kebutuhan mahasiswa. Setelah itu akan dilakukan telaah silabus dilakukan untuk mengetahui kompetensi umum dan kompetensi khusus yang bertujuan untuk menentukan ruang lingkup, kedalaman serta keluasan materi. Kegiatan berikutnya yaitu analisis pembelajaran yang bertujuan untuk menentukan urutan-urutan kompetensi khusus sehingga bisa membentuk ketercapaian kompetensi umum. Kemudian dilanjutkan dengan perancangan dan pengembangan bahan ajar berbasis kasus yang kemudian divalidasi oleh ahli kemudian direvisi sesuai dengan komentar/masukan dari validator sehingga hasil penelitian untuk tahun pertama yaitu bahan ajar yang telah divalidasi oleh ahli. Berikut ini tabel tentang jabaran kegiatan penelitian.

Tabel 1. Jabaran Kegiatan Penelitian

\begin{tabular}{|c|c|}
\hline Kegiatan & Indikator \\
\hline $\begin{array}{l}\text { 1. } \begin{array}{l}\text { Pengembangan } \\
\text { berbasis kasus }\end{array} \\
\end{array}$ & $\begin{array}{l}\text { Draft awal bahan ajar berbasis kasus } \\
\text { mencakup } 4 \text { pokok bahasan. }\end{array}$ \\
\hline 2. Validasi bahan ajar berbasis kasus & $\begin{array}{l}\text { Draft bahan ajar yang telah } \\
\text { divalidasi oleh subject matter expert } \\
\text { sehingga diperoleh bahan ajar siap } \\
\text { diuji cobakan }\end{array}$ \\
\hline 3.Uji coba bahan ajar & $\begin{array}{l}\text { Hasil pretest dan posttest kelas } \\
\text { kontrol dan kelas eksperimen }\end{array}$ \\
\hline $\begin{array}{l}\text { 4. Revisi, evaluasi, dan implementasi } \\
\text { bahan ajar. }\end{array}$ & $\begin{array}{l}\text { Bahan ajar yang siap dipakai dalam } \\
\text { proses pembelajaran. }\end{array}$ \\
\hline
\end{tabular}

Berdasarkan tabel 1 dapat disimpulkan bahwa ada 4 kegiatan yang diteliti pada tahap pengembangan bahan ajar ini yaitu menyusun draft awal bahan ajar dan validasi bahan ajar, uji coba bahan ajar, serta revisi dan evaluasi bahan ajar. Jabaran komponen bahan ajar yang akan dikembangkan terdiri dari judul, apersepsi, petunjuk belajar, daftar isi, tujuan pembelajaran, studi kasus, materi, daftar rujukan dan sumber belajar pendukung.

Instrumen penelitian digunakan untuk: (1) memvalidasi produk bahan ajar yang akan dilakukan oleh ahli/subjec matter expert. Instrumen dikembangkan berdasar kisikisi yang dikembangkan oleh Kim, et al. (2006) yang meliputi 4 kategori yaitu content, structure, atribute dan process. Kategori pertama adalah tentang content/isi yaitu strategi yang terkait dengan ruang lingkup isi kasus. Struktur adalah strategi yang terkait dengan desain kasus, sedangkan atribut terkait dengan penentuan tujuan kasus, serta 
proses adalah strategi yang terkait dengan proses pembelajaran. Setiap kategori sesuai dengan konsepnya terdiri dari sub-sub atau indikator-indikator penjabarannya. Instrumen ke (2) digunakan untuk mengevaluasi bahan ajar oleh mahasiswa pada saat uji coba. Berdasar kisi-kisi tersebut kemudian dikembangkan pertanyaan-pertanyaan untuk menilai bahan ajar. Spesifikasi produk untuk penelitian ini yaitu draf bahan ajar menggunakan pendekatan studi kasus yang dirancang untuk 11 (sebelas) bab seperti tercantum pada tabel di berikut ini.

Tabel 2. Materi Bahan Ajar

\begin{tabular}{|l|l|}
\hline Bab & Pokok Bahasan/Materi \\
\hline 1 & Sistem dan Azas Hukum di Indonesia \\
\hline 2 & Hukum Perjanjian \\
\hline 3 & Bentuk Badan Usaha: Perusahaan perseorangan, Firma, dan CV \\
\hline 4 & Kaedah Hukum Bentuk Badan Usaha Perseroan Terbatas (PT) \\
\hline 5 & Hukum Perlindungan Konsumen \\
\hline 6 & Hak atas Kekayaan Intelektual I (Hak cipta, Hak Paten) \\
\hline 7 & $\begin{array}{l}\text { Hak atas Kekayaan Intelektual II (Desain Industri, Hak merek, Rahasia } \\
\text { Dagang) }\end{array}$ \\
\hline 8 & Hukum Persaingan Usaha \\
\hline 9 & Hukum Pasar Modal \\
\hline 10 & Hukum Kepailitan dan Penundaan Kewajiban Pembayaran Utang \\
\hline 11 & Arbitrase dan Alternatif Penyelesaian Sengketa Bisnis \\
\hline
\end{tabular}

Teknik analisis yang digunakan untuk menilai bahan ajar yang telah divalidasi oleh ahli adalah analisis deskriptif kuantitatif yaitu analisis persentase berdasar kisi-kisi yang dikembangkan dari instrumen. Dari analisis ini dapat diketahui apakah bahan ajar terkategori sangat valid, valid, cukup atau kurang valid. Adapun untuk menilai keefektifan bahan ajar pada saat uji coba digunakan uji t dari kelas kontrol dan kelas eksperimen. Keefektifan bahan ajar dinilai berdasar feedback dari mahasiswa berdasar angket yang juga dikembangkan dalam penelitian ini. Dengan demikian bahan ajar dievaluasi baik oleh ahli/expert maupun pengguna yaitu mahasiswa.

\section{HASIL DAN PEMBAHASAN}

Langkah pertama yang dilakukan untuk mengembangkan bahan ajar ini yaitu melakukan analisis kebutuhan dengan cara menyebar kuesioner pada mahasiswa yang telah menempuh matakuliah Aspek Hukum Ekonomi dan Bisnis. Secara umum kegiatan analisis kebutuhan ini ingin mengetahui kesulitan-kesulitan belajar, penyebabnya, 
ketersediaan bahan ajar yang relevan sehingga dengan informasi ini dapat dijadikan acuan untuk merancang bahan ajar yang sesuai kompetensi dan kebutuhan mahasiswa. Hasil analisis kebutuhan dapat dilihat pada tabel berikut:

Tabel 3. Cara Mahasiswa Mempelajari Hukum Bisnis

\begin{tabular}{|l|c|c|c|c|}
\hline \multicolumn{1}{|c|}{ Keterangan } & Frequency & Percent & $\begin{array}{c}\text { Valid } \\
\text { Percent }\end{array}$ & $\begin{array}{c}\text { Cumulative } \\
\text { Percent }\end{array}$ \\
\hline Membaca Buku & 44 & 65.7 & 65.7 & 65.7 \\
\hline $\begin{array}{l}\text { Membaca UU dan } \\
\text { Peraturan Terkait }\end{array}$ & 11 & 16.4 & 16.4 & 82.1 \\
\hline $\begin{array}{l}\text { Browsing kasus- } \\
\text { kasus hukum bisnis }\end{array}$ & 6 & 9.0 & 9.0 & 91.0 \\
\hline $\begin{array}{l}\text { Analisis kasus-kasus } \\
\text { hukum bisnis }\end{array}$ & 6 & 9.0 & 9.0 & 100.0 \\
\hline Total & 67 & 100.0 & 100.0 & \\
\hline
\end{tabular}

Berdasarkan tabel 3 dapat dilihat bahwa 65\% mahasiswa membaca buku aspek hukum ekonomi dan bisnis, sebesar 16,4\% membaca Undang-undang dan peraturan terkait, sebesar 9\% browsing kasus-kasus hukum dan sisanya hanya sebesar 9\% mahasiswa yang mempelajari matakuliah Aspek Hukum Ekonomi dan Bisnis dengan menganalisis kasus-kasus hukum bisnis.

Tabel 4. Kesulitan yang dihadapi mahasiswa dalam mempelajari Humbis

\begin{tabular}{|l|c|c|c|c|}
\hline \multicolumn{1}{|c|}{ Keterangan } & Frequency & Percent & $\begin{array}{c}\text { Valid } \\
\text { Percent }\end{array}$ & $\begin{array}{c}\text { Cumulative } \\
\text { Percent }\end{array}$ \\
\hline Selalu & 57 & 85,1 & 85,1 & 85,1 \\
\hline Kadang-kadang & 7 & 10,4 & 10,4 & 95,5 \\
\hline Jarang & 2 & 3.0 & 3.0 & 98.5 \\
\hline Tidak pernah & 1 & 1.5 & 1.5 & 100.0 \\
\hline Total & 67 & 100.0 & 100.0 & \\
\hline
\end{tabular}

Berdasarkan tabel 4 nampak bahwa sebagian besar mahasiswa mengalami kesulitan dalam mempelajari Aspek Hukum Ekonomi dan Bisnis sebanyak 85,1\% dan sisanya hanya mengalami sedikit kesulitan. 
Tabel 5. Penyebab Kesulitan dalam Mempelajari Humbis

\begin{tabular}{|l|c|c|c|c|}
\hline \multicolumn{1}{|c|}{ Keterangan } & Frequency & Percent & $\begin{array}{c}\text { Valid } \\
\text { Percent }\end{array}$ & $\begin{array}{c}\text { Cumulativ } \\
\text { e Percent }\end{array}$ \\
\hline Merasa asing dengan bahasa hukum & 34 & 50.7 & 50.7 & 50.7 \\
\hline $\begin{array}{l}\text { Pembahasan materi di buku kurang } \\
\text { lengkap }\end{array}$ & 7 & 10.4 & 10.4 & 61.2 \\
\hline $\begin{array}{l}\text { Tidak ada contoh-contoh kasus } \\
\text { hukum bisnis }\end{array}$ & 8 & 11.9 & 11.9 & 73.1 \\
\hline Kurang latihan soal & 17 & 25.4 & 25.4 & 98.5 \\
\hline Tidak menjawab & 1 & 1.5 & 1.5 & 100.0 \\
\hline Total & 67 & 100.0 & 100.0 & \\
\hline
\end{tabular}

Berdasarkan tabel 5 tampak bahwa sebanyak 50,7\% mahasiswa merasa asing dengan bahasa hukum dan sebanyak 10,4\% mengatakan bahwa pembahasan materi di buku kurang lengkap dan sebanyak 11,9\% mengatakan bahwa tidak ada contoh-contoh kasus hukum bisnis dan sebanyak 25,4\% mahasiswa mengatakan bahwa tidak adanya latihan soal menyebabkan mahasiswa kesulitan dalam mempelajari aspek hukum ekonomi dan bisnis.

Tabel 6. Karakteristik Buku Hukum Bisnis yang Dimiliki Mahasiswa

\begin{tabular}{|l|c|c|c|c|}
\hline \multicolumn{1}{|c|}{ Keterangan } & Frequency & Percent & $\begin{array}{c}\text { Valid } \\
\text { Percent }\end{array}$ & $\begin{array}{c}\text { Cumulative } \\
\text { Percent }\end{array}$ \\
\hline Mengadopsi dan menyalin UU & 11 & 16.4 & 16.4 & 16.4 \\
\hline $\begin{array}{l}\text { Memaparkan konsep hukum bisnis } \\
\text { semata }\end{array}$ & 29 & 43.3 & 43.3 & 59.7 \\
\hline $\begin{array}{l}\text { Tidak ada contoh-contoh kasus } \\
\text { hukum bisnis }\end{array}$ & 20 & 29.9 & 29.9 & 89.6 \\
\hline Tidak ada latihan soal & 6 & 9.0 & 9.0 & 98.5 \\
\hline Tidak menjawab & 1 & 1.5 & 1.5 & 100.0 \\
\hline Total & 67 & 100.0 & 100.0 & \\
\hline
\end{tabular}

Berdasarkan tabel 6 diketahui bahwa sebanyak 43,3\% buku-buku yang dimiliki oleh mahasiswa hanya memaparkan konsep hukum bisnis semata dan sebanyak 29,9\% mengatakan bahwa buku-buku yang mereka miliki tidak ada contoh-contoh kasus hukum bisnis dan sisanya mengatakan bahwa buku-buku yang ada hanya menyalin dari Undang-undang dan tidak ada latihan soal. 
Tabel 7. Kuantitas Mahasiswa Membaca Bahan Ajar Kasus

\begin{tabular}{|l|c|c|c|c|}
\hline \multicolumn{1}{|c|}{ Keterangan } & Frequency & Percent & $\begin{array}{c}\text { Valid } \\
\text { Percent }\end{array}$ & $\begin{array}{c}\text { Cumulative } \\
\text { Percent }\end{array}$ \\
\hline Tidak Pernah & 55 & 82.1 & 82.1 & 82.1 \\
\hline pernah & 10 & 14.9 & 14.9 & 97.0 \\
\hline $\begin{array}{l}\text { Tidak } \\
\text { menjawab }\end{array}$ & 2 & 3.0 & 3.0 & 100.0 \\
\hline Total & 67 & 100.0 & 100.0 & \\
\hline
\end{tabular}

Berdasarkan hasil analisis kebutuhan tersebut diketahui bahwa rata-rata mahasiswa belajar matakuliah aspek hukum ekonomi dan bisnis hanya membaca buku dan Undang-undang serta peraturan terkait sehingga hal inilah yang menyebabkan mahasiswa kesulitan untuk memahami matakuliah aspek hukum ekonomi dan bisnis karena mahasiswa merasa tidak ada contoh-contoh kasus hukum bisnis dimana sebagian besar buku aspek hukum ekonomi dan bisnis hanya menyalin dan mengadopsi dari Undang-undang saja. Berdasarkan analisis kebutuhan tersebut juga diketahui bahwa rata-rata belajar mahasiswa untuk mempelajari matakuliah aspek hukum ekonomi dan bisnis kurang dari 2 jam dan sumber belajar yang digunakan hanya 2 buku. Dengan kondisi ini, maka diperlukan bahan ajar yang dapat menunjang belajar mahasiswa yaitu bahan ajar yang berupa contoh kasus untuk membantu mereka memahami materi. Dengan adanya contoh kasus tersebut mereka berharap dapat mengaitkan konsep hukum bisnis kedalam aplikasinya dan mampu untuk menginterpretasi dan mengkritisi faktafakta kasus hukum bisnis.

Pada tahap kegiatan telaah silabus telah dihasilkan pemetaan kompetensi umum dan kompetensi khusus yang terdiri dari 11 (sebelas) pokok bahasan. Tujuan telaah silabus ini adalah untuk menentukan ruang lingkup, kedalaman dan keluasan materi. Adapun pada tahap kegiatan analisis pembelajaran bertujuan untuk menentukan urutanurutan kompetensi khusus sehingga bisa membentuk ketercapaian kompetensi umum. Bahan ajar yang telah dihasilkan dari kegiatan penelitian pengembangan ini menggunakan pendekatan studi kasus yang dirancang untuk 11 (sebelas) bab seperti tercantum pada tabel 8 berikut: 
Tabel 8. Materi Bahan Ajar

\begin{tabular}{|l|l|}
\hline Bab & Pokok Bahasan/Materi \\
\hline 1 & Sistem dan Azas Hukum di Indonesia \\
\hline 2 & Hukum Perjanjian \\
\hline 3 & Bentuk Badan Usaha: Perusahaan perseorangan, Firma, dan CV \\
\hline 4 & Kaedah Hukum Bentuk Badan Usaha Perseroan Terbatas (PT) \\
\hline 5 & Hukum Perlindungan Konsumen \\
\hline 6 & Hak atas Kekayaan Intelektual I (Hak cipta, Hak Paten) \\
\hline 7 & Hak atas Kekayaan Intelektual II (Desain Industri, Hak merek, Rahasia Dagang) \\
\hline 8 & Hukum Persaingan Usaha \\
\hline 9 & Hukum Pasar Modal \\
\hline 10 & Hukum Kepailitan dan Penundaan Kewajiban Pembayaran Utang \\
\hline 11 & Arbitrase dan Alternatif Penyelesaian Sengketa Bisnis \\
\hline
\end{tabular}

Setiap pokok bahasan ditentukan kompetensi khusus atau tujuan pembelajarannya. Kemudian dari 11 (sebelas) pokok bahasan tersebut kemudian dikembangkan bahan ajar dengan pendekatan studi kasus dengan komponen-komponen yang harus terpenuhi sebagai syarat sebuah bahan ajar. Komponen tersebut meliputi judul, apersepsi, petunjuk belajar, daftar isi, tujuan pembelajaran, studi kasus, materi, soal latihan dan daftar rujukan. Berdasarkan komponen tersebut, tampak bahwa produk yang dikembangkan dan dihasilkan telah sesuai dengan komponen-komponen yang harus dimiliki oleh ciri khusus bahan ajar diantaranya adalah: apersepsi, petunjuk belajar, dan tujuan pembelajaran. Namun demikian sebagai produk hasil penelitian bahan ajar ini tetap harus melalui proses validasi khususnya dari ahli sebagaimana yang telah dijelaskan di rancangan penelitian dan prosedur penelitian pada bab tiga. Oleh karena itu perlu dibuat instrumen untuk mengevaluasi bahan ajar ini.

Instrumen yang digunakan dalam penelitian ini bersifat skala likert dengan tujuan agar validator/evaluator bisa secara fleksibel dan komprehensif menilai bahan ajar. Adapun kisi-kisi dari instrumen evaluasi bahan ajar yaitu content (kesesuaian isi), 
structure (bahasa dan lay out), atribute (tujuan kasus) dan process (proses pembelajaran). Berikut adalah hasil validasi bahan ajar oleh 2 orang vaidator.

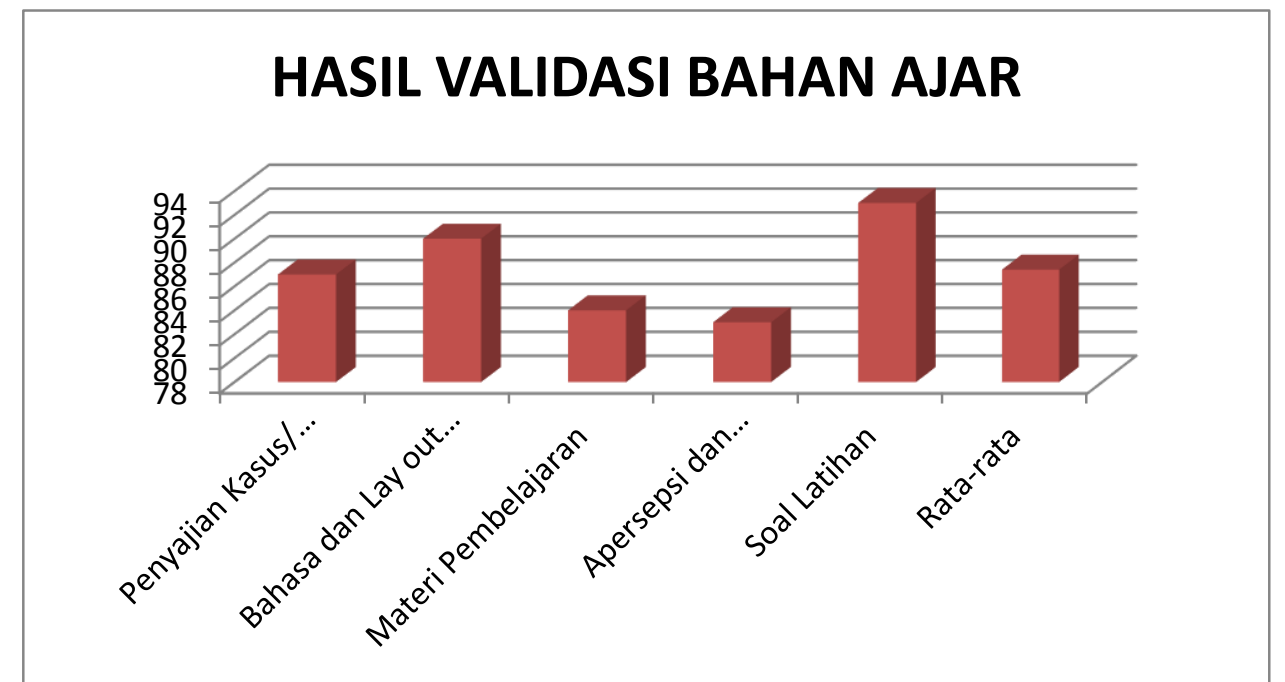

\section{Gambar 1. Hasil Validasi Bahan Ajar}

Bagan diatas menunjukkan bahwa pada komponen penyajian kasus ini terdapat 12 item dimana kisaran penilaian bahan ajar oleh validator antara sangat tinggi dan tinggi. Hasil validasi pada komponen penyajian kasus dari 2 validator menunjukkan bahwa masing-masing sebesar 88 dan 86 dengan rata-rata 87 . Berdasarkan interval nilai hasil validasi bahan ajar pada tabel 2 tersebut maka dikategorikan valid. Pada komponen bahasa dan lay out bahan ajar ini terdapat 10 item dimana kisaran penilaian bahan ajar oleh validator antara sangat tinggi dan tinggi. Hasil validasi pada komponen penyajian kasus dari 2 validator menunjukkan bahwa masing-masing sebesar 90 dan 90 dengan rata-rata 90. Berdasarkan interval nilai hasil validasi bahan ajar pada tabel 2 tersebut maka dikategorikan sangat valid. Pada komponen materi pembelajaran ini terdapat 12 item dimana kisaran penilaian bahan ajar oleh validator antara sangat tinggi dan tinggi. Hasil validasi pada komponen penyajian kasus dari 2 validator menunjukkan bahwa masing-masing sebesar 91 dan 77 dengan rata-rata 84. Pada komponen materi pembelajaran ini terdapat 8 item dimana kisaran penilaian bahan ajar oleh validator antara sangat tinggi dan tinggi. Hasil validasi pada komponen penyajian kasus dari 2 validator menunjukkan bahwa masing-masing sebesar 75 dan 92 dengan rata-rata 83 . Berdasarkan interval nilai hasil validasi bahan ajar pada tabel 2 tersebut maka dikategorikan valid. Pada komponen materi pembelajaran ini terdapat 3 item dimana kisaran penilaian bahan ajar oleh validator antara sangat tinggi dan tinggi. Hasil 
validasi pada komponen penyajian kasus dari 2 validator menunjukkan bahwa masingmasing sebesar 93 dan 93 dengan rata-rata 93. Berdasarkan interval nilai hasil validasi bahan ajar pada tabel 2 tersebut maka dikategorikan sangat valid valid. Secara keseluruhan dapat dikatakan bahwa bahan ajar berbasis kasus pada matakuliah Aspek Hukum adalah valid.

\section{SIMPULAN DAN SARAN}

Penelitian ini merupakan penelitian dan pengembangan yang mengacu pada model Borg dan Gall ( 1983) yang terdiri dari 8 langkah. Penelitian ini dilakukan dalam dua tahap/dua tahun dimana tahap pertama prosedur penelitian meliputi telaah silabus, analisis pembelajaran, perancangan dan pengembangan bahan ajar, validasi ahli kemudian direvisi sesuai dengan masukan dari validator sehingga hasil akhirnya adalah bahan ajar yang telah divalidasi. Pada tahap berikutnya yaitu di tahun kedua, penelitian akan dilanjutkan dengan hasil tahun pertama yaitu bahan ajar yang telah divalidasi kemudian diujicobakan kepada mahasiswa, direvisi sesuai masukan mahasiswa/user kemudian finalisasi bahan ajar yang dilanjutkan dengan diseminasi dan implementasi bahan ajar di kelas. Keefektifan bahan ajar dilihat dengan cara uji coba/eksperimen di kelas.

Untuk penelitian berikutnya diharapkan dapat mengembangkan bahan ajar Aspek Hukum Ekonomi dan Bisnis dengan pendekatan yang lain dan menggunakan uji coba sampel yang lebih besar sehingga pengembangan bahan ajar yang dilakukan dapat mengakomodir kebutuhan mahasiswa yang jauh lebih banyak pula.

\section{DAFTAR PUSTAKA}

Anderson. J.R., 1985, Language, Memory and Thougth, Hilsade, NJ, Erlabum

Bonner, S.E dan P.L. Walker, 1994. The Effects of Instruction an experience on The Acqui Auditing Knowledge, The Accounting Review 69, No 1.

Borg, R.w.,\& Gall, D., 1983. Educational Research an Introduction, Fourth edition. Longman, New York.

Mutmainah, Siti. 2011. Pengaruh Penerapan Metode Pembelajaran Kooperatif Berbasis Kasus yang Berpusat Pada Mahasiswa terhadap efektivitas Pembelajaran Akuntansi Keperilakuan. Simposium Nasional Akuntansi

Kim, Sara.,Phillips, R., Pinsky, L.,Brock,D.,Phillips,K., Keary,J. 2006. Medical Education. P.867-876. 
Yumarma, Andreas. 2006. Pedagogi Pasca-UU Guru dan Dosen. Kompas 